\title{
EGG HATCHING RATES OF BROWN-MARBLED GROUPER, EPINEPHELUS FUSCOGUTTATUS UNDER DIFFERENT LIGHT WAVELENGTHS AND INTENSITIES
}

\section{Siti Nasihin Mohammad Seth, Nai Han Tan, Muhammad Khairulanwar Rosli, Shahbudin Saad, Normawaty Mohammad Noor and Yukinori Mukai*}

Kulliyyah of Science, International Islamic University Malaysia, Jalan Sultan Ahmad Shah, 25200 Kuantan, Pahang. *Corresponding author: mukai9166@gmail.com

\begin{abstract}
This study was conducted to examine the egg hatching rates of brown-marbled grouper, Epinephelus fuscoguttatus under different light conditions in terms of light wavelengths and intensities. Results of two-way ANOVA showed significant difference for light wavelengths $(p<0.05)$, while light intensities showed no significant difference. There was no interaction between light wavelengths and intensities. Post-hoc Tukey test showed that hatching rates under green light wavelength were significantly higher than white and yellow light wavelengths $(p<0.05)$. When white light $2.7 \mu \mathrm{moles} / \mathrm{m}^{2} / \mathrm{s}$ was set as the control, the hatching ratio of the brownmarbled grouper under green light $2.7 \mu \mathrm{moles} / \mathrm{m}^{2} / \mathrm{s}$ was almost three times higher than the control. The lowest ratio of hatching rates was observed under the white light $13.3 \mu \mathrm{moles} / \mathrm{m}^{2} / \mathrm{s}$ with 70 percent lower ratio of hatching rates than the control light. Eggs hatching under other light conditions mostly showed higher ratios than the control light.
\end{abstract}

\begin{abstract}
ABSTRAK Kajian ini dijalankan untuk mengkaji kadar penetasan telur kerapu harimau, Epinephelus fuscoguttatus di bawah keadaan cahaya yang berbeza dari segi jarak gelombang dan keamatan. Keputusan ANOVA dua hala menunjukkan panjang gelombang cahaya menunjukkan perbezaan yang signifikan $(p<0.05)$, manakala tiada perbezaan yang signifikan bagi keamatan cahaya. Panjang gelombang cahaya dan keamatan cahaya tidak berkaitan antara satu sama lain dalam mempengaruhi penetasan telur ikan kerapu harimau. Keputusan ujian post-hoc Tukey telah menunjukkan kadar penetasan di bawah panjang gelombang cahaya hijau adalah jauh lebih signifikan daripada cahaya putih dan cahaya panjang gelombang kuning $(p<0.05)$. Apabila cahaya putih $2.7 \mu \mathrm{mol} / \mathrm{m}^{2} / \mathrm{s}$ ditetapkan sebagai kawalan, nisbah penetasan ikan kerapu harimau di bawah cahaya hijau $2.7 \mu \mathrm{mol} / \mathrm{m}^{2} / \mathrm{s}$ adalah hampir tiga kali ganda lebih tinggi daripada kawalan. Nisbah kadar penetasan paling rendah diperhatikan di bawah cahaya putih $13.3 \mu \mathrm{mol} / \mathrm{m}^{2} / \mathrm{s}$, dengan nisbah kadar penetasan 70 peratus lebih rendah daripada kawalan. Telur menetas di bawah keadaan cahaya yang lain kebanyakannya menunjukkan nisbah yang lebih tinggi daripada kawalan.
\end{abstract}

(Keywords: Brown-marbled grouper, Epinephelus fuscoguttatus, light wavelengths, light intensities, egg hatching rates)

\section{INTRODUCTION}

Egg hatching rates vary depending on several factors such as temperature [1], salinity [2], dissolved oxygen [3], and light environment [4]. Light conditions affect the growth and development of aquatic living things [5]. Some studies have been done on various light conditions for incubation of teleost eggs. For example, studies of light intensities on haddock (Melanogrammus aeglefinus) eggs show that the eggs are not affected by light intensity [4]. Haddock eggs stay in the upper $50 \mathrm{~m}$ in the sea and the eggs are exposed to highly variable light environment. Therefore, haddock eggs are adaptive to wider range of light intensity [4]. Incubations of rainbow trout (Salmo irideus Gibbons) and Atlantic halibut (Hippoglossus hippoglossus) eggs are optimum under dim light conditions [6 and 7]. Incubation of Walleye Pollock (Theragra chalcogamma) eggs is optimum under dark condition [8]. Studies of egg incubation under different light wavelengths show that hatching rates of Senegal sole (Solea senegalensis) and zebrafish (Danio rerio) are the highest when the eggs are incubated under blue light wavelength [9 and 10]. Studies of egg incubation show that light conditions are speciesspecific and related to their natural habitats $[4,6,7$, $8,9$ and 10$]$.

Brown-marbled grouper, Epinephelus fuscoguttatus is widely distributed in the Indo-Pacific Ocean including the Red Sea [11]. It is an important species for aquaculture in Southeast Asia [12 and 13]. However, only few studies have been done on its 
early developmental stage [14]. The optimum light condition for its egg incubation is still unknown. Therefore, this study was conducted to examine the optimum light wavelength and intensity for brownmarbled grouper egg incubation.

\section{MATERIALS AND METHODS}

Brown-marbled grouper eggs were obtained from the brood stock in the hatchery of Institute of Oceanography and Maritime Studies (INOCEM), International Islamic University Malaysia (IIUM). The eggs were incubated in $40 \mathrm{~L}$ aquaria $[60 \mathrm{~cm}(\mathrm{~L})$ x $29 \mathrm{~cm}(\mathrm{~W})$ x $32 \mathrm{~cm}(\mathrm{H})$ ] with triplicate in dark room, using light emitting diode (LED) (10W high power LED, Wayjun Technology Co., Ltd, Shenzhen, China) lamps with different light wavelengths: white (broad spectrum with double peaks $452,557 \mathrm{~nm}$ ) as control, blue (peak, $458 \mathrm{~nm})$, green (528 nm), yellow
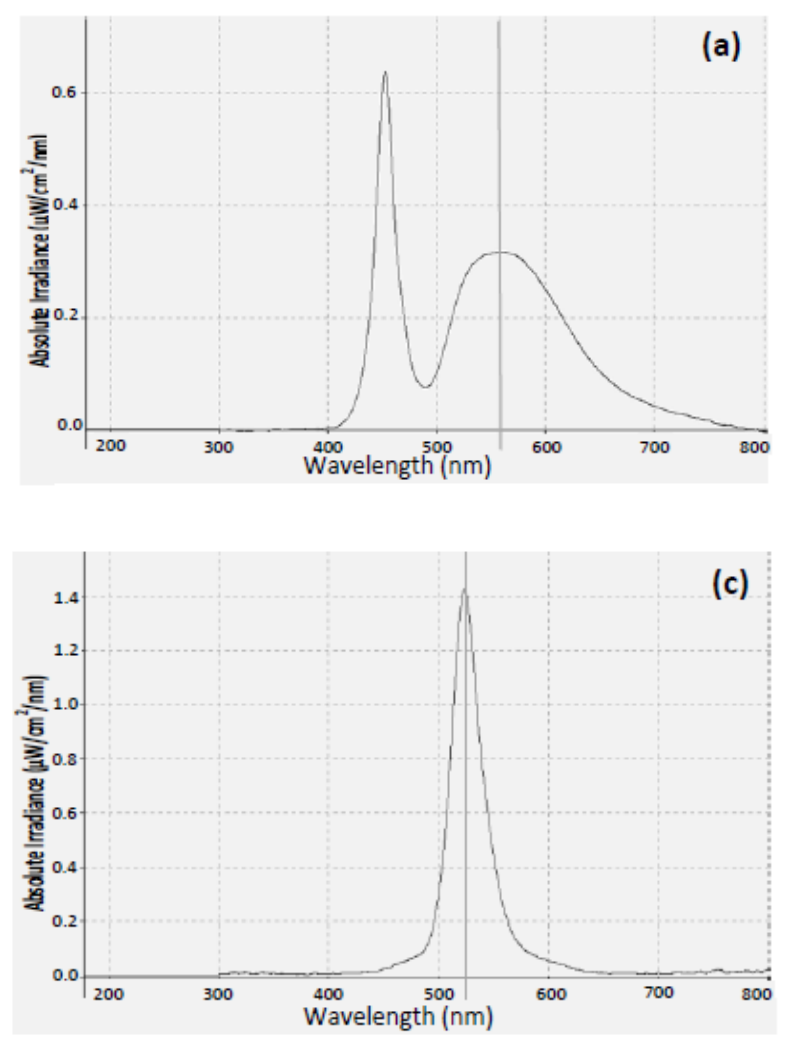

Figure 1. Graphs of light wavelengths (a) white,
(593 nm), and red $(636 \mathrm{~nm})$ (Figure 1). Light intensities for each wavelength were set at $0.53,2.7$, and $13.3 \mu \mathrm{moles} / \mathrm{m}^{2} / \mathrm{s}$. The spectral wavelengths and light intensities of LED lamps were measured at the water surface using a spectrometer (USB4000, Ocean Optics, Inc., Florida, USA). The water depth was 20 $\mathrm{cm}$. The light conditions were set up as 0600 on and 1800 off. The water salinity and the temperature in the incubation aquaria were $31 \mathrm{ppt}$ and $27.5-28.5^{\circ} \mathrm{C}$, respectively. Nannochloropsis sp. frozen paste (Nannochloropsis K2, New World Aqua, Busan, Korea) was put at the density of 1 million cells $/ \mathrm{ml}$ in each aquarium. In general, brown-marbled grouper spawn at night [15]. The eggs hatched at 24 hours after spawning, and then the number of larvae was counted to examine the hatching rates. Statistical analysis was done using two-way ANOVA with two factors, light wavelengths and light intensities (SPSS version 15).
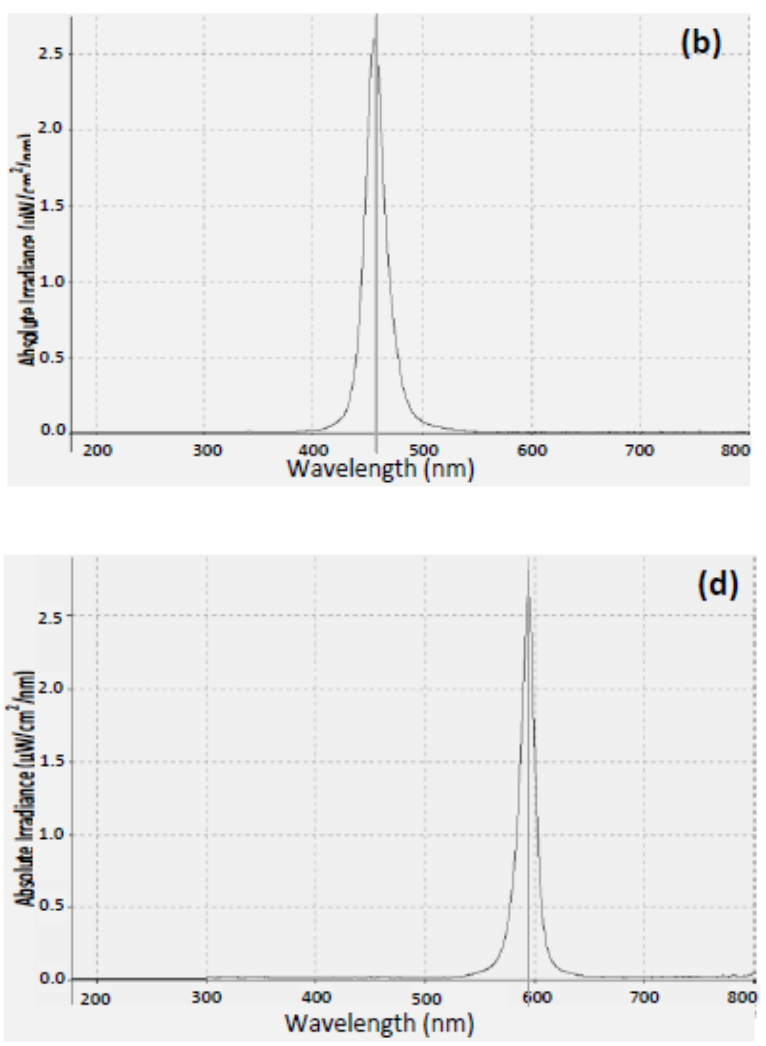

(b) blue, (c) green, (d) yellow and (e) red. 


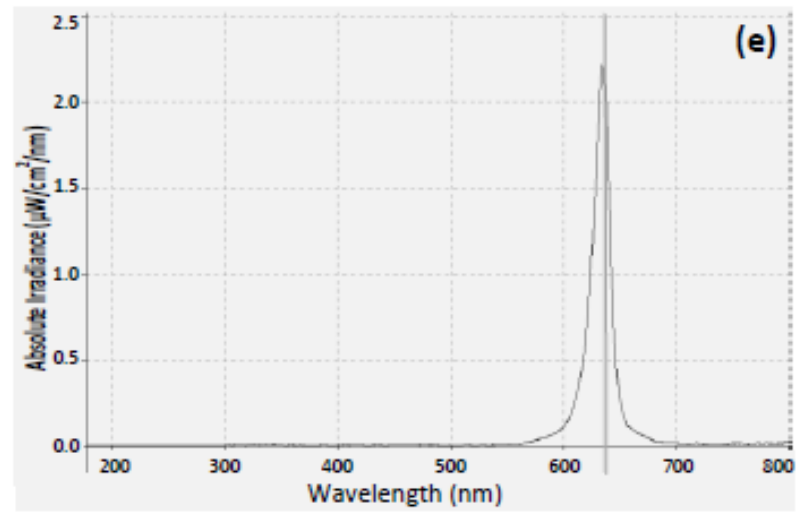

Figure 1 (Cont'd.).Graphs of light wavelengths (a) white, (b) blue, (c) green, (d) yellow and (e) red.

\section{RESULTS}

Results of two-way ANOVA showed significant difference for light wavelengths $(p<0.05)$, while light intensities showed no significant difference (Table 1). There was no interaction between light wavelengths and intensities. Post-hoc Tukey test showed green light wavelength was significantly higher than white and yellow light wavelengths $(p<0.05)$ (Table 2). Table 3 shows result of post-hoc Tukey test for light intensities. Although there was no significant difference, there was a tendency of higher hatching rates when the eggs were incubated under 2.7 $\mu \mathrm{moles} / \mathrm{m}^{2} / \mathrm{s}$. Figure 2 shows the ratios of hatching rates under different light wavelengths and intensities relative to white light $2.7 \mu \mathrm{moles} / \mathrm{m}^{2} / \mathrm{s}$ as control. The hatching ratios under green light $2.7 \mu \mathrm{moles} / \mathrm{m}^{2} / \mathrm{s}$ showed almost three times higher than the control light. Blue light 13.3, green light 0.53 and 13.3 , and red light $13.3 \mu \mathrm{moles} / \mathrm{m}^{2} / \mathrm{s}$ showed double hatching ratios compared to the control.

Table 1. Two-way ANOVA of light intensities and wavelengths. Light intensities showed no significant difference while light wavelengths showed significant difference $(p<0.05)$. There was no interaction between light intensities and wavelengths.

\begin{tabular}{lllll}
\hline Source & $\boldsymbol{d} \boldsymbol{f}$ & Mean Square & $\boldsymbol{F}$ & $\boldsymbol{p}$ \\
\hline Intensity & 2 & 921 & 2.019 & .150 \\
Wavelength & 4 & 2770 & 6.071 & $.001^{*}$ \\
Intensity $\times$ Wavelength & 8 & 473 & 1.036 & .432 \\
\hline
\end{tabular}

*Significant difference

Table 2. Post-hoc Tukey test for light wavelengths regarding hatching rates of brown-marbled grouper egg. Hatching rate under green light wavelength was significantly higher than hatching rates under white and yellow light wavelengths.

\begin{tabular}{cccccc}
\hline & White & Blue & Green & Yellow & Red \\
\hline White & --- & --- & --- & --- & --- \\
Blue & 0.086 & --- & --- & --- & --- \\
Green & $0.001^{*}$ & 0.440 & --- & --- \\
Yellow & 0.961 & 0.299 & $0.007^{*}$ & --- & --- \\
Red & 0.097 & 1.000 & 0.405 & 0.329 & --- \\
\hline
\end{tabular}

*Significant difference $(p<0.05)$ 
Table 3. Post-hoc Tukey test for light intensities $\left(\mu \mathrm{moles} / \mathrm{m}^{2} / \mathrm{s}\right)$ regarding egg hatching rates of brown-marbled grouper. There was no significant difference between groups.

\begin{tabular}{cccc}
\hline & 0.53 & 2.7 & 13.3 \\
\hline 0.53 & --- & --- & -- \\
2.7 & 0.147 & --- & -- \\
13.3 & 0.878 & 0.331 & --- \\
\hline
\end{tabular}

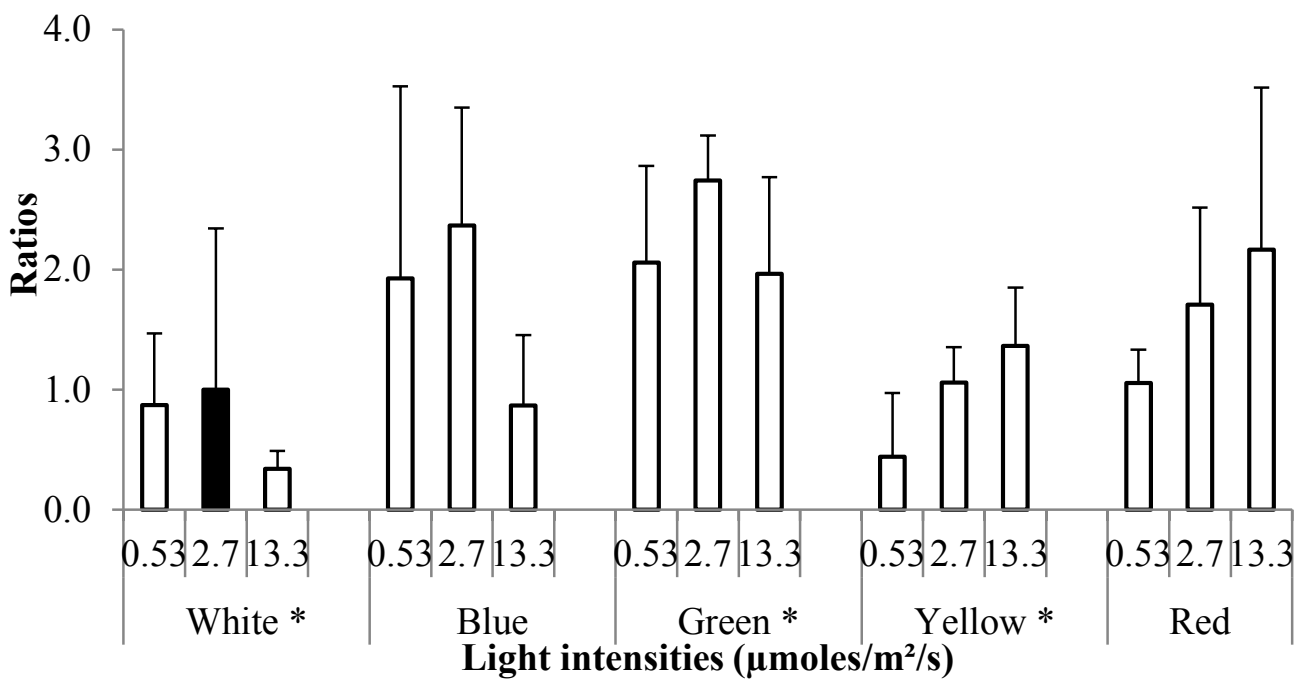

Figure 2. Results of egg hatching ratios of brown-marbled grouper, Epinephelus fuscoguttatus. Light conditions were blue, green, yellow, red and white with light intensities $0.53,2.7$, and $13.3 \mu \mathrm{moles} / \mathrm{m}^{2} / \mathrm{s}$. Egg hatching ratios compared with white light as control (as white $2.7 \mu \mathrm{moles} / \mathrm{m}^{2} / \mathrm{s}$ is 1.0 ). ${ }^{*}$ Post-hoc Tukey test showed the egg hatching ratios under green light were significantly higher than white and yellow light $(p<0.05)$.

\section{DISCUSSION}

In this study, the egg hatching rates were influenced by light wavelengths and intensities. From our results (Figure 2), the highest ratio of hatching rates was shown when the eggs were put under the green light wavelength. White light wavelength, which represented the typical fluorescent lamp in most hatcheries, showed the lowest ratio of hatching rates. The lowest ratio of hatching rates was observed under the white light $13.3 \mu \mathrm{moles} / \mathrm{m}^{2} / \mathrm{s}$, with 70 percent lower ratio of hatching rates than the control light (white light $2.7 \mu \mathrm{moles} / \mathrm{m}^{2} / \mathrm{s}$ ). Yellow and red light $13.3 \mu \mathrm{moles} / \mathrm{m}^{2} / \mathrm{s}$ showed slightly higher hatching ratios than the control light.

In terms of light wavelengths, the significantly higher hatching ratios under the green light wavelength might be due to the natural habitats of the brownmarbled grouper at their early life stage. Compared to white light wavelength, blue and green light wavelengths showed higher hatching ratios for brown-marbled grouper as these lights probably provided suitable lighting for the eggs to hatch.

Present results are similar to the incubation of zebrafish eggs which is optimum under shorter light wavelength (blue) [10]. The study suggests blue light wavelength relates to the development of pineal organ during embryo stage of zebrafish [10]. The pineal organ, which is one of the sensory organs located in the brain and associated with light sensitivity, might have developed at the embryo stage of brown-marbled grouper. Further investigation is needed to confirm the function of the pineal organ in the brown-marbled grouper embryo stage.

In terms of light intensities, there was a tendency of higher ratio of hatching rates under blue and green light $2.7 \mu \mathrm{moles} / \mathrm{m}^{2} / \mathrm{s}$, while under yellow and red light wavelengths the ratios of hatching rates tend to increase with light intensities. Although further studies are needed to investigate the effects of higher light intensities in yellow and red light wavelengths, results of post-hoc Tukey test showed that green light wavelength was significantly higher than white and 
yellow light wavelengths. Therefore, it can be suggested that green light $2.7 \mu \mathrm{moles} / \mathrm{m}^{2} / \mathrm{s}$ is the optimum light condition for brown-marbled grouper egg incubation.

\section{CONCLUSION}

Egg hatching rates of brown-marbled grouper, Epinephelus fuscoguttatus were influenced by light conditions. In this study, green light $2.7 \mu$ moles $/ \mathrm{m}^{2} / \mathrm{s}$ was an optimum condition for the egg incubation of brown-marbled grouper. It can be estimated that the eggs stay in the water area where blue and green light are dominant.

\section{ACKNOWLEDGEMENT}

This study was supported by the e-Science Fund (0401-08-SF0116) of the Ministry of Science, Technology and Innovation of Malaysia (MOSTI).

\section{REFERENCES}

1. Watanabe W. O., Lee C. S., Ellis S. C. and Ellis E. P. (1995). Hatchery study of the effects of temperature on eggs and yolksac larvae of the Nassau grouper, Epinephelus striatus. Aquaculture 136: $141-147$.

2. Faris A. A. and Wootton R. J. (1987). Effect of water $\mathrm{pH}$ and salinity on the survival of eggs and larvae of the euryhaline teleost, Gasterosteus aculeatus L.. Environmental Pollution 48: 49 - 59.

3. DiMichelle L. and Taylor M. H. (1980). The environmental control of hatching in Fundulus heteroclitus. Journal of Experimental Biology 214: $181-187$.

4. Downing G. and Litvak M. K. (2002). Effects of light intensity, spectral composition and photoperiod on development and hatching of haddock (Melanogrammus aeglefinus) embryos. Aquaculture 213: 265 - 278.

5. Esteban M. A., Cuesta A., Pozo E. C. and Meseguer J. (2013). Influence of melatonin on the immune system of fish: a review. International Journal of Molecular Science 14: 7979 - 7999.

6. Bieniarz K. (1973). Effect of light and darkness on incubation of eggs, length, weight and sexual maturity of sea trout (Salmo trutta L.), brown trout (Salmo trutta fario L.) and rainbow trout (Salmo irideus Gibbons). Aquaculture 2: 299 - 315.
7. Forsell J., Holmqvist B., Helvik J. V. and Ekstrom P. (1997). Role of the pineal organ in the photoregulated hatching of the Atlantic halibut. International Journal of Developmental Biology 41: $591-595$.

8. Olla B. L. and Davis M. W. (1993). The influence of light on egg buoyancy and hatching rate of walleye pollock, Theragra chalcogamma. Journal of Fish Biology 42: 693 - 698.

9. Blanco-Vives B., Aliaga-Guerrero M., Cañavate J. P., Muñoz-Cueto J. A. and Sánchez-Vázquez F. J. (2011). Does lighting manipulation during incubation affect hatching rhythms and early development of sole? Chronobiology International 28(4): $300-306$.

10. Villamizar N., Vera L. M., Foulkes N. S. and Sánchez-Vázquez F. J. (2014). Effect of lighting conditions on zebrafish growth and development. Zebrafish 11(2): 173 - 181 .

11. Heemstra P. C. and Randall J. E. (1993). FAO Species Catalogue Vol. 16. Groupers of the world (family Serranidae, subfamily Epinephelinae), an annotated and illustrated catalogue of the grouper, rockcod, hid, coral grouper and lyretail species known to date. Food and Agriculture Organization of the United Nations. Rome, I, II.

12. Kohno H., Diani S. and Supriatna A. (1993). Morphological development of larval and juvenile grouper, Epinephelus fuscogttatus. Japanese Journal of Ichthyology 40: 307 - 316.

13. Lim L. C., Chao T. M. and Khoo L. T. (1990). Observations on the breeding of brown-marbled grouper, Epinephelus fuscoguttatus (Forskål). Singapore Journal of Primary Industries 18: 66 84.

14. Mukai Y., Lim L. S., Kien C. L., Mohamed Kamil A. R. and Shahbudin S. (2012). Light intensity requirements for feeding behaviour by the brown-marbled grouper, Epinephelus fuscoguttatus. Sains Malaysiana 41: 1193 - 1196.

15. Sugama K., Trijoko W., Heriadi E., Ismi S. and Kawahara S. (2002). Breeding and larval rearing of barramundi cod (Cromileptes altivelis) in captivity. In: APEC/NACA Cooperative Grouper Aquaculture Workshop, Hat Yai, Thailand,PP. 9199. 